\title{
CHROMOSOME STUDIES \\ ON EUROPEAN SPECIES OF THE GENERA ANEURA AND RICCARDIA (HEPATICAE)
}

\section{J. L. D. MEENKS ${ }^{1}$}

Vakgroep populatie- en evolutiebiologie, Padualaan $8,3584 \mathrm{CH}$ Utrecht

\section{INTRODUCTION}

Until recently relatively little attention has been paid to the study of chromosomes in liverworts. The first substantial contributions were made by HeITZ $(1927,1928)$ and LORBEER (1934). In the second half of this century chromosome studies on liverworts were mainly carried out in Europe (e.g. FRITSCH 1972; Newton 1977, 1979) and Japan (e.g. TAtuno 1959; Segawa 1965a, b, c; INOUE 1968), Inoue (in KOPONEN 1979) reports that until now $28 \%$ of all bryophyte species in Japan have been investigated as to their chromosome complement. A comprehensive, but rather outdated, survey of chromosome numbers in Hepaticae and Anthocerotae was given by BERRIE (1960). Work on a new, updated survey is now underway (FRITSCH, in prep.).

In the present article results are presented of a cytotaxonomic investigation of European species of the genera Aneura and Riccardia (Aneuraceae). Most specimens were gathered in the Netherlands, but some chromosome counts based on French and German plants are also included.

\section{MATERIALS AND METHODS}

The liverworts were collected in the field in the period of march-august 1980 , and subsequently cultivated during several months in growth chambers at $14^{\circ} \mathrm{C}$ and illuminated 12 hours a day. Specimens were grown in transparent, closed plastic boxes on a substrate consisting of garden mould and sand (1:1), and were watered every two days.

Plant material was gathered in the following localities:

\section{The Netherlands}

1. Staverden (Prov. of Gelderland)

2. Utrecht (Prov. of Utrecht)

3. Wassenaar (Prov. of Zuid-Holland)

4. Kortenhoef (Prov. of Utrecht)

5. Dronten (Oostelijk Flevoland)

${ }^{1}$ Present address of the author: Instituut voor Systematische Plantkunde, Postbus 80.102, 3508 TC Utrecht. 


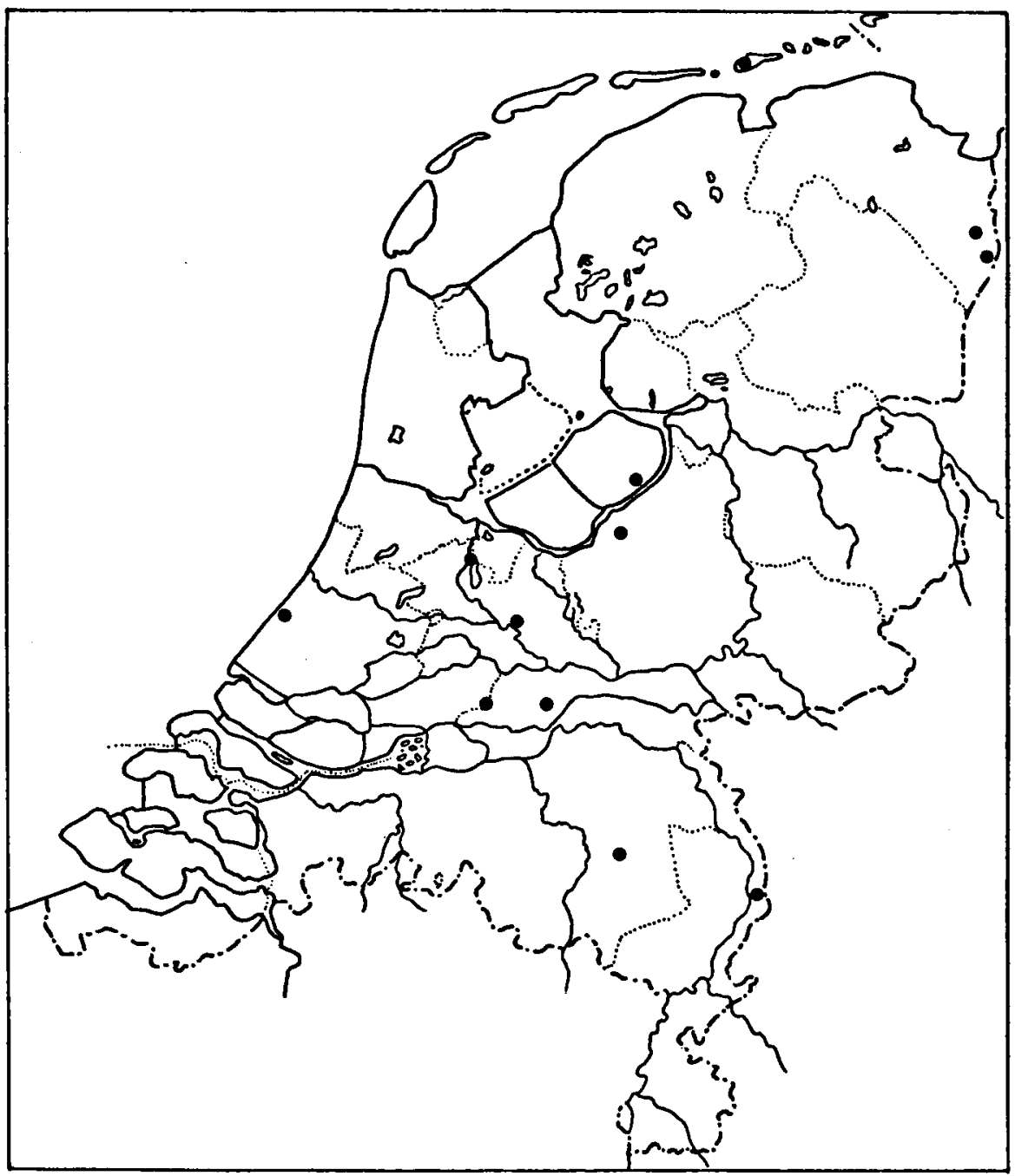

Fig. 1. Map, showing the distribution of the Netherlands populations investigated.

6. Venlo (Prov. of Limburg)

7. Buren (Prov. of Gelderland)

8. Asperen (Prov. of Zuid-Holland)

9. Oosterburen (Isle of Schiermonnikoog)

10. Bourtange (Prov. of Groningen)

11. Onstwedde (Prov. of Groningen)

12. Eindhoven (Prov. of Noord-Brabant)

France

13a, b, c. Nant (Dept. Aveyron), 3 different populations 
West Germany

14. Herrenstrunden (Nordrhein-Westfalen)

Voucher specimens have been deposited in the herbarium of the State University of Utrecht (U) in the Netherlands. Thallus apices of growing gametophytes were fixed in Karpechenko's fixative, embedded in paraffin-wax and sectioned at $12 \mu \mathrm{m}$ on a microtome. The chromosomes were stained according to Heidenhain's haematoxylin method.

\section{RESULTS}

Four species of the Aneuraceae were investigated:

Riccardia chamedrifolia, $R$. multifida, $R$. incirvata and Aneura pinguis. The results are given below, including the localities of the specimens concerned. Examples of karyograms determined are given in fig. 2.

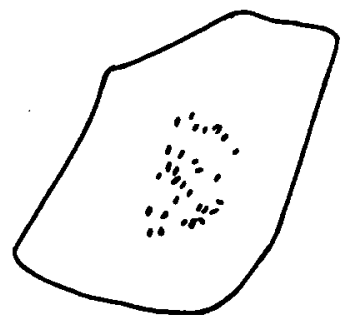

a

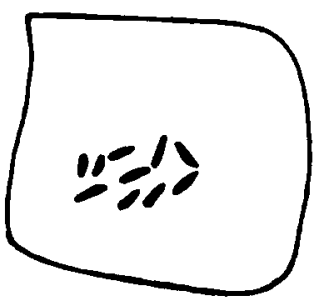

d

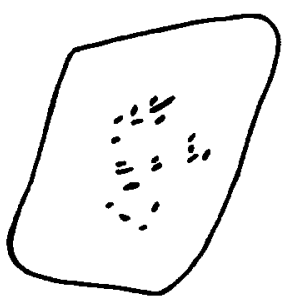

b

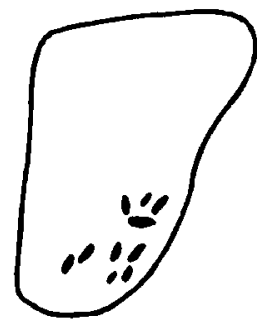

e
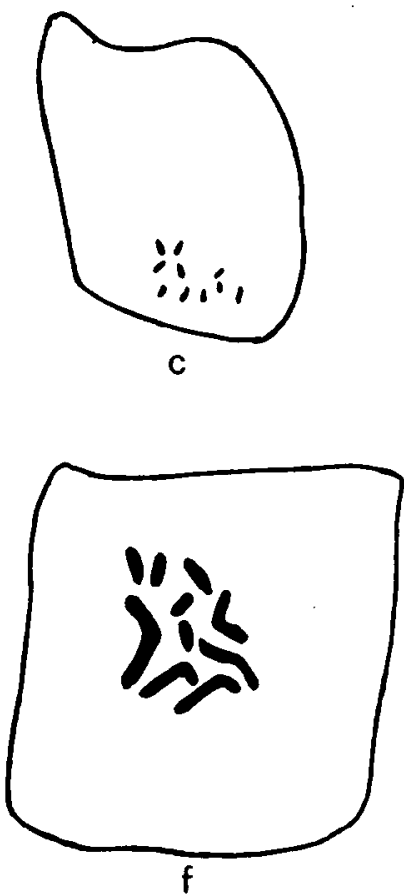

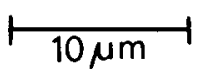

Fig. 2. Karyograms of the investigated species (schematic). a. Riccardia chamedrifolia (Kortenhoef); b. R. multifida (Kortenhoef); c. R. incurvata (Staverden); d. R. incurvata (Venlo); e. R. incurvata (Schiermonnikoog); f. Aneura pinguis (Wassenaar). 
Riccardia chamedrifolia (With.) Grolle

Localities: 1, 4, 5, 6, 7, 8, 10,11,12,13a, 13b, and 13c.

In the 12 populations investigated the chromosome number $\mathbf{n}=30$ was found. This is in agreement with an earlier count by LORBEER (1934). NEWTON (1971) reports $\mathrm{n}=20$ for British material, a number also indicated by the results of HEITZ (1928).

\section{Riccardia multifida (L.) Gray}

Locality: 4.

The chromosome number observed in the single population investigated was $n=20$. The same number was found in plants of Central Europe by HeITz (1928) and LORBEER (1934), while NewtON (1971) refers a number of $n=c$. 19 for an Irish specimen.

Riccardia incurvata Lindb.

Localities: 1,6 and 9.

In this species a chromosome number of $n=10$ was observed. The difference in size between the chromosomes of the populations investigated is striking (cf. fig. $2 c, 2 d$ and $2 e$ ). This chromosomal difference could, however, not be correlated with morphological features. Chromosome counts of $n=10$ for $R$. incurvata are also reported for Central Europe (LoRBEER 1934) and Great-Britain (NEwTON 1975).

\section{Aneura pinguis (L.) Dum.}

Localities: 1, 2, 3, 4, 5, 6, 7, 8, 9, 13a, 13b, 13c and 14 .

The haploid complement consists of $5 \mathrm{~V}$ - and $5 \mathrm{~J}$-shaped chromosomes (fig. 2f), which are nearly always larger (3-8 $\mu \mathrm{m})$ than the chromosomes of the investigated Riccardia species $(1-3 \mu \mathrm{m})$. The chromosome number $\mathrm{n}=10$ in $A$. pinguis is known from North-America (SHOwalter 1923), Central Europa (HEITZ 1927; LoRbeER 1934), Japan (TATUNo 1941 ; InOue 1977), Great-Britain (NEWTON 1971) and Colombia (Meenks, unpubl.). In a chromosome study on arctic liverworts INOUE (1976) reports for $A$. pinguis $\mathrm{n}=10$ and also a polyploid race of $n=20$.

\section{DISCUSSION}

While the chromosome numbers in Hepaticae in general seem to be very constant, nevertheless many polyploids are known in the Aneuraceae (BERRIE 1966). In the genus $A$ neura the chromosome numbers $n=10$ and $n=20$ are known, as well as $\mathrm{n}=8$ in the Australian A. alterniloba (BERrIe 1962; Hewson 1970a). The latter number might either be a dysploid of $n=10$ or the result of doubling a complement of 4 chromosomes. In the latter case $n=10$ could be the polyploid of $n=4+1$. Among the European species of the genus Riccardia the chromosome numbers $n=10, n=20$ and $n=30$ are found. Furthermore BERRIE (1966) indicates $\mathrm{n}=\mathbf{4 0}$ for West African specimens of $R$. stephanii. In her study on 
Australian Riccardia's Hewson (1970b) reports for both $R$. babindae and $R$. cochleata $\mathrm{n}=10$ and $\mathrm{n}=20$.

Polyploidy often results from the fact that a gametophyte contains a separate male and female genome (LewIS 1961). Possibly this might refer to the monoecious species Riccardia chamedrifolia $(\mathrm{n}=30)$ and $R$. multifida $(\mathrm{n}=20)$, the dioecious species $R$. incurvata and Aneura pinguis having $\mathrm{n}=10$. Polyploidy might, however, also result from speciation in response to environmental extremes (LEWIS 1966). This could be an explanation for the origin of the polyploid arctic Aneura pinguis discovered by INOUE (1976). It is also important to note that many Aneuraceae species are growing in pioneer vegetations, where speciation coupled with polyploidy is relatively common (STEBBINs 1966). The rather common occurrence of polyploids in Aneuraceae may thus be explained.

\section{ACKNOWLEDGEMENTS}

The author is much indebted to Miss G. Zijlstra, dr. F. J. A. Daniëls, Prof. R. Düll, dr. S. R. Gradstein and dr. B. O. van Zanten for help in collecting specimens. He is also indebted to 'Staatsbosbeheer Nederland' which provided facilities for collecting material in areas owned by this association. Furthermore he wishes to express his gratitude to dr. S. R. Gradstein and dr. E. Kliphuis for their critical remarks and for correcting the English text.

\section{REFERENCES}

BERRIE, G. K. (1960): The chromosome numbers of liverworts (Hepaticae and Anthocerotae). Trans. Brit. bryol. Soc. 3: 688-705.

- (1962): The chromosome numbers of some Australian Liverworts. Proc. Linn. Soc. N.S.W. 84: 305-306.

- (1966): Polyploidy in some West African species of Riccardia (Gray). Revue bryol. lichen. 34: 302-308.

FriTSCH, R. (1972): Chromosomenzahlen der Bryophyten, eine Übersicht und Diskussion ihres Aussagewertes für das System. Wiss. Z. Friedrich Schiller-Univ. Jena, Math. Nat. Reihe 21 : 839-944.

- (in prep.): Index of chromosome numbers in bryophytes. Regn. Veget. Utrecht.

Heitz, E. (1927): Úber multiple und aberrante Chromosomenzahlen. Abh. naturw. Ver. Hamburg 21: $47-58$.

- (1928): Das.Heterochromatin der Moose 1. Jb. wiss. Bot. 69 : 762-818.

Hewson, H. J. (1970a): The family Aneuraceae in Australia and New Guinea: 1. The genus Aneura.

Proc. Linn. Soc. N.S.W. 94: 173-193.

- (1970b): The family Aneuraceae in Australia and New Guinea: 2. The genus Riccardia. Proc. Linn. Soc. N.S.W. 95: 60-121.

INOUE, H. (1968): Chromosome numbers of some Malayan and Taiwan liverworts. Bull Natn. Sci. Mus. Tokyo 11 : 397-403.

- (1976): Chromosome studies in some Arctic Hepatics. Bull. natn. Sci. Mus. ser. B 2: 39-46.

- (1977): Chromosome numbers of some Japanese Hepaticae (2). Bull. natn. Sci. Mus. ser. B 3: 55-61.

KOPONEN, T. (1979): A historical review of Japanese bryology. In: Bryophyte systematics (G. C. S. Clarke \& J. G. Duckett, eds.), pp. 159-183. Academic Press, London and New York.

LEwIS, H. (1966): Speciation in flowering plants. Science 152: 167-172.

LEWIS, K. R. (1961): The genetics of bryophytes. Trans. Brit. bryol. Soc. 4: 111-130.

LORBEER, G. (1934): Die Zytologie der Lebermoose mit besonderer Berücksichtigung allgemeiner Chromosomenfragen 1. Jb. wiss. Bot. 80: 567-818. 
Newton, M. E. (1971): Chromosome studies in some British and Irish bryophytes. Trans. Brit. bryol. Soc. 6: 244-257.

- (1975): Chromosome studies in some British bryophytes. J. Bryol. 8: 365-382.

- (1977): Heterochromatin as a cyto-taxonomic character in liverworts: Pellia, Riccardia and Cryptothallus. J. Bryol. $9:$ 327-342.

- (1979): Chromosome morphology and bryophyte systematics. In: Bryophyte systematics (G. C. S. Clarke \& J. C. DucketT, eds.), pp. 207-229. Academic Press, London and New York.

Segawa, M. (1965a): Karyological studies in liverworts, with special reference to structural sex chromosomes. 1. J. Sci. Hiroshima Univ. ser. B, div. 2 10: 69-80.

- (1965b): Karyological studies in liverworts, with special reference to structural sex chromosomes. 11. J. Sci. Hiroshima Univ. ser. B, div. 2 10: 81-148.

- (1965c): Karyological studies in liverworts, with special reference to structural sex chromosomes. 111. J. Sci. Hiroshima Univ. ser. B, div. 2 10: 149-178.

Showalter, A. M. (1923): The chromosomes of Riccardia pinguis. Am. J. Bot. 10: 170-172.

SteBBiNs, G. L. (1966): Chromosomal variation and evolution. Science 152: 1463-1469.

TATUNO, S. (1941): Zytologische Untersuchungen über die Lebermoose von Japan. J. Sci. Hiroshima Univ. ser. B, div. $24: 73-187$.

- (1959): Chromosomen von Takakia lepidozioides und eine Studie zur Evolution der Chromosomen der Bryophyten. Cytologia 24: 138-147. 